\title{
PRELIMINARY ASSESSMENT OF COASTAL EROSION AND LOCAL COMMUNITY ADAPTATION IN SAYUNG COASTAL AREA, CENTRAL JAVA - INDONESIA
}

\author{
MUH ARIS MARFAI \\ Universitas Gadjah Mada, Faculty of Geography, Bulaksumur, Yogyakarta-Indonesia
}

Manuscript Received: March 16, 2012

Revised Version: July 25, 2012

Marfai M.A., 2012. Preliminary assessment of coastal erosion and local community adaptation in Sayung coastal area, central Java - Indonesia. Quaestiones Geographicae 31(3), Bogucki Wydawnictwo Naukowe, Poznań 2012, pp. 47-55. 8 Figs. DOI 10.2478/v10117-012-0028-2, ISSN 0137-477X.

ABSTRACT. Dynamic environment in coastal area, especially due to coastal erosion process, has negative impact on human environment. Sayung coastal area, located in Central Java-Indonesia, has experienced severe impact of coastal erosion. As the result of the coastal erosion, hundreds of settlement located in coastal area has been destructed. Moreover, fishponds as the land use dominated in the coastal area also has been severely destroyed. Besides the coastal erosion, increasing of inundated area due to sea level rise also threaten the local community. Although devastating impact suffering the coastal area, the people of Tambaksari, as the part of Sayung area, decided to live and adapt with the coastal erosion. This paper aims to identify the coastal erosion and understand adaptation strategies held by the local community related to reduce the impact of the coastal erosion. Based on this research, various adaptation strategies has been identified, namely (1) Planting mangrove alongside the shoreline, (2) elevating the ground level, (3) building staged house, (4) utilizing deep well for freshwater supply, (5), maintaining social interaction with mainland community, (6) Collecting fish from the mangrove as the food, and (7) changing work into the tourism sector.

KEY wORDS: Coastal erosion, Community adaptation strategies, Sayung coastal area

Muh Aris Marfai, Faculty of Geography, Universitas Gadjah Mada, Bulaksumur 55281, Yogyakarta-Indonesia, e-mail:arismarfai@yahoo.com/arismarfai@gadjahmada.edu

\section{Introduction}

Coastal area, as an intersection of the natural processes generated from the land and the sea, has very dynamic environment compared to the other locations in the world. Natural process from the land, mainly driven by fluvial process, is produced as the result of water flowing from mountainous catchment area to the lowland delta (Marfai \& Mardiatno 2010). The fluvial proc- ess reaching the outlet therefore combined with the process from the sea, mainly driven by the wave and current. As summarized by Marfai et al. (2008), Marfai et al. (2011), Marfai (2011a), Mardiatno et al. (2012), and Purnama et al. (2012), various physical and geomorphological processes generated by the interaction of the land and the sea can be found, for example; tsunami, coastal inundation, river flooding, land subsidence, erosion and sedimentation, degradation of 
mangrove ecosystem, environmental pollution, and problem related to water resources. Geomorphological processes occurred in coastal area, especially in the terms of erosion and sedimentation, are the most important factor to the shoreline changes. The process of continuous erosion and sedimentation become major driven factor of shoreline changes as one of the most dynamic process in coastal area (Bagli \& Soille 2003, Sunarto 2004, Mills et al. 2005)

Indonesian archipelago has very complex geomorphological process occurred in both the land and the sea. The Indonesian shoreline, which extents of more than $80,000 \mathrm{~km}$ in length, therefore might face various environmental problems. Marfai (2011b) stated that inundation, displacement of wetlands and lowlands, increased coastal storm flooding, and increased salinity are the most serious problems suffering coastal area. Several coastal areas in Indonesia also suffered from shoreline changes due to coastal erosion. While parts coastal-lowland topography in Indonesia is dominated by settlement, economic activities, and agriculture, the coastal area in Indonesia has very high vulnerability (Marfai \& King 2007). Moreover, due to inappropriate land use management, the environmental problems in Indonesian coastal area are continuously getting worse (Marfai \& King 2008). However, coastal community usually adapt with the situation by developing kind of coping strategies. Starting from simple structural mitigation up to massive structural defense (Marfai et al. 2008a, Marfai et al. 2009, Marfai 2011c, Hardoyo et al. 2011).

Sayung coastal area, as part of the coastal area in Demak Regency (North of Central Java - Indonesia), has affected by dynamical process in the form of shoreline changes. As noted by Marfai et al. (2008b), Sartohadi et al. (2009), and Maulina (2010), most dynamic area of erosion-sedimentation process in Central Java can be found in Semarang City, Tegal Regency, and Demak Regency. Although various erosion and sedimentation process can be found in the northern coast of Central Java (Bird \& Ongkosongo 1980, Sunarto 2004, Marfai et al. 2008b), Sayung coastal area has experienced massive coastal erosion. At present, coastal erosion has damaged mangrove ecosystem, settlement, and fish pond. The impact of coastal erosion towards fish pond and settlement in Sayung becomes source of major economic losses towards local community. In adapting the impact of the coastal erosion, local community in the research area has developing specific adaptation strategies. Therefore, it is important to identify and understand adaptation strategies held by the local community, especially in developing future mitigation and adaptation strategies.

\section{Objectives}

This research aims to (1) analyze the dynamic of shoreline changes in Sayung area due to coastal erosion, (2) analyze the impact of coastal erosion toward local community in research area, (3) identify adaptation strategies taken by the local community at present.

\section{Methodology}

Analysis of shoreline changes due to coastal erosion and analysis of adaptation strategies of the local community in Tambaksari-Sayung area have been applied in this research. Analysis of shoreline change is calculated based on visualtemporal remote sensing data. Landsat satellite image in 1994 has been applied to represent the past condition in which the impact of erosion was small. Analysis of shoreline changes then has been done by comparing it with Landsat image in 2006. Therefore, the coastal erosion can be visually identified using both of the two images.

Adaptation strategies of the local community has identified by using in depth interview to the community member. The aspects that have been identified consist of both physical and social-economic aspects. Besides the physical and socialeconomic adaptation, community perception about the coastal erosion and community preference in adaptation also gathered.

\section{Result and discussion}

\subsection{Coastal Erosion in Sayung}

Sayung coastal area, as part of Demak Regency, is located at the regency boundary with the 
East of Semarang City (Fig. 1). At present, Sayung coastal area is highly affected by economic development in Semarang. Whereas Semarang City functioned as one of the center of regional economic center in Java, the Sayung coastal area then become supported area related to the growing economic activities in Semarang. Therefore, this location has a role as a hinterland connector of Kedungsepur regional economic zone. As the impact of regional economic development in the zone, not only economic and business activities which have been affected, but also the physicalenvironmental process, especially in the coastal area.
Sayung coastal area has flat-lowland topography with the elevation of about 0-10 meters above sea level. While the location has low elevation bordering the sea, sedimentation process is taken place. Therefore, the alluvial sediment with very fine texture can be found in the location. Sediment materials especially come from Kendeng and Muria upper catchment area, which are mountainous region located in the eastern part of Demak. Erosional process comes from the mountainous region resulted in the movement of the soil material from the upper part to the lower part of the region. This process is highly influenced by the fluvial process comes from the river.

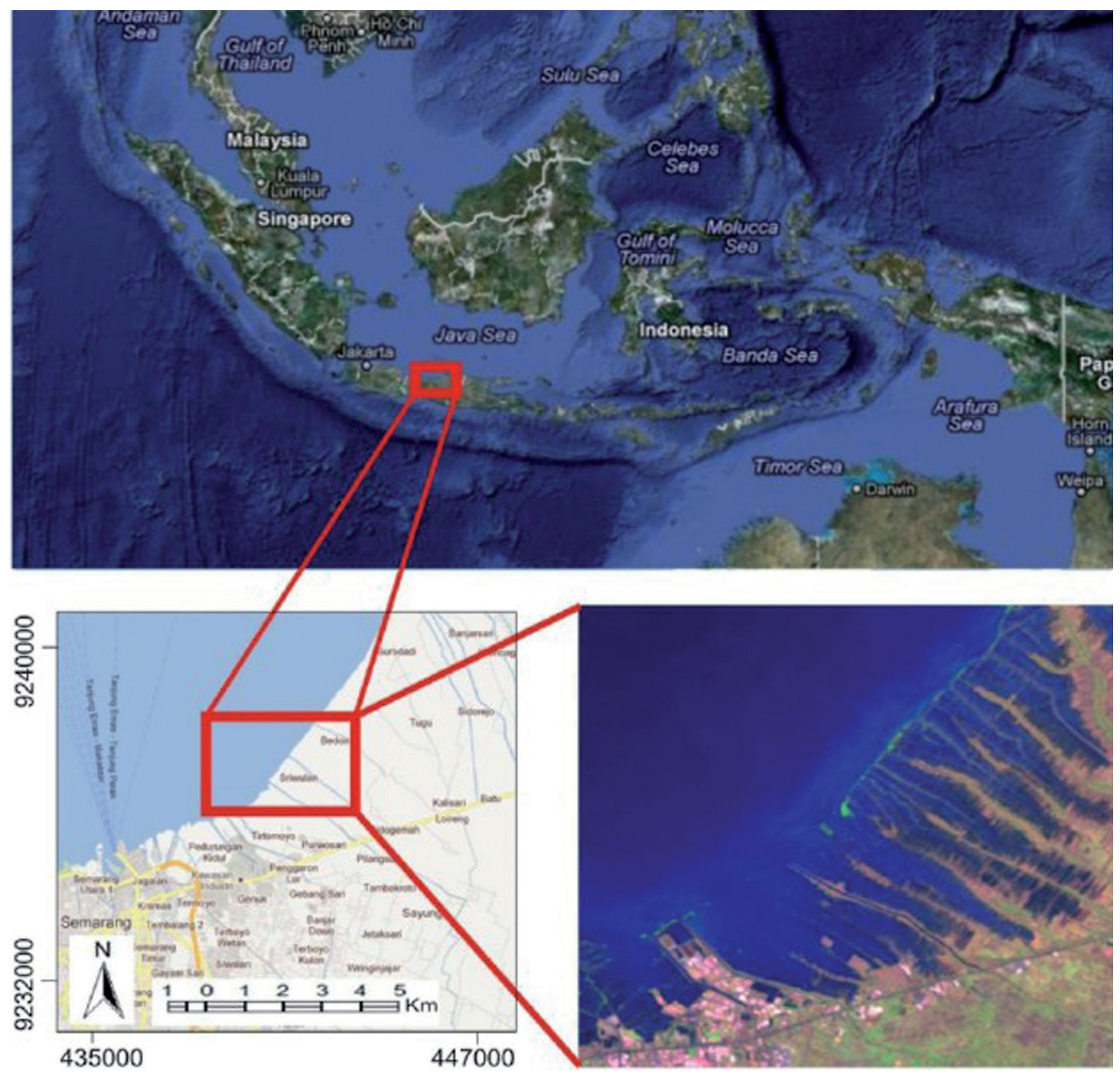

Fig. 1. Map of the study area. 
In the study area, river which has major role on the sediment distribution is Wulan River, located in the North part of Sayung.

In the past, sedimentation becomes dominant process in the study area, resulting in the development of lowland area of Sayung. Unfortunately, due to development of economic activities in Semarang, the dynamic process occurred in Sayung changed pretty much. In 1987, devel-

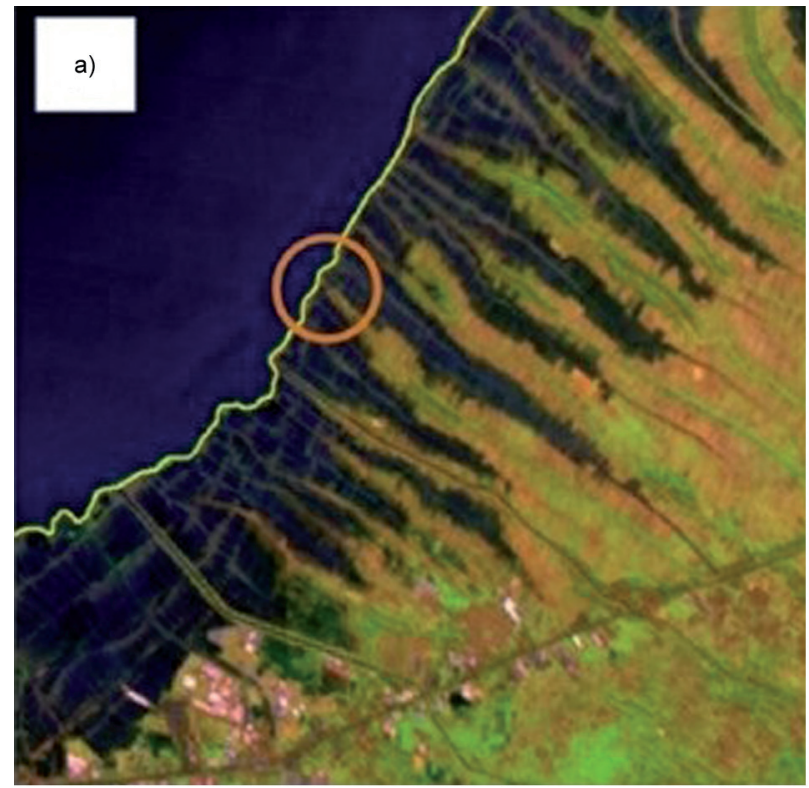

Shoreline opment of Tanjung Mas and Marina Bay started in East part of Semarang. This condition resulted in bigger coastal erosion in Sayung. In 1998, eleven years after the Bay was started, the impact of coastal erosion began to destroy the fishpond and inundated local settlement. Coastal erosion was continuously getting bigger in 1999 and then started to destroy the settlement. In 2000, 208 household was evacuated to the saver place be-

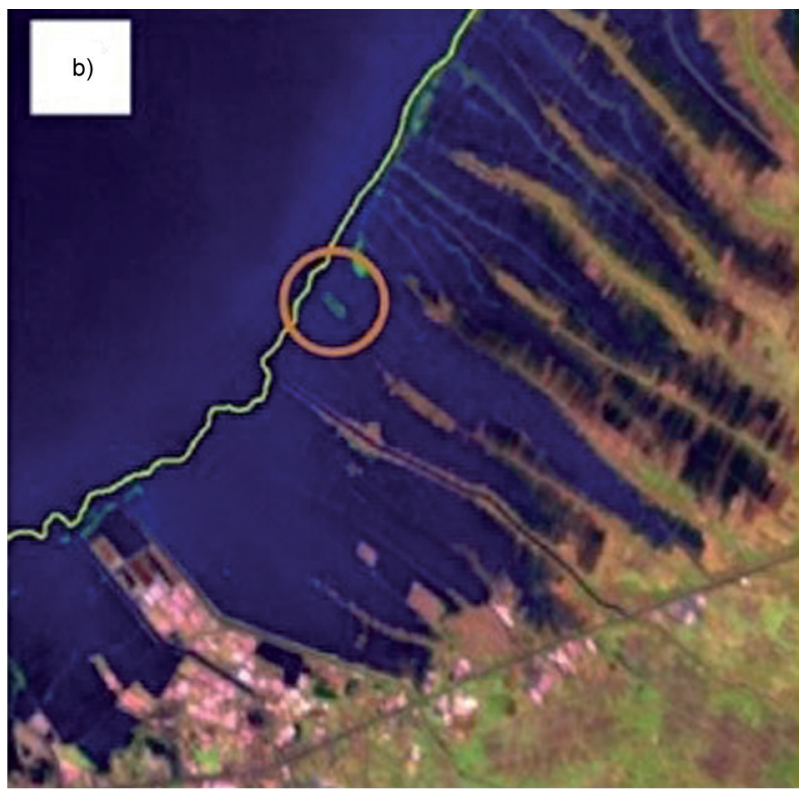

Tambaksari-Sayung Area

Fig. 2. Changes of shoreline due to the coastal erosion.

(a) Landsat images in 1994 shown that the area still united as the mainland. (b) Landsat images in 2006 shown the study location is separated from the mainland.

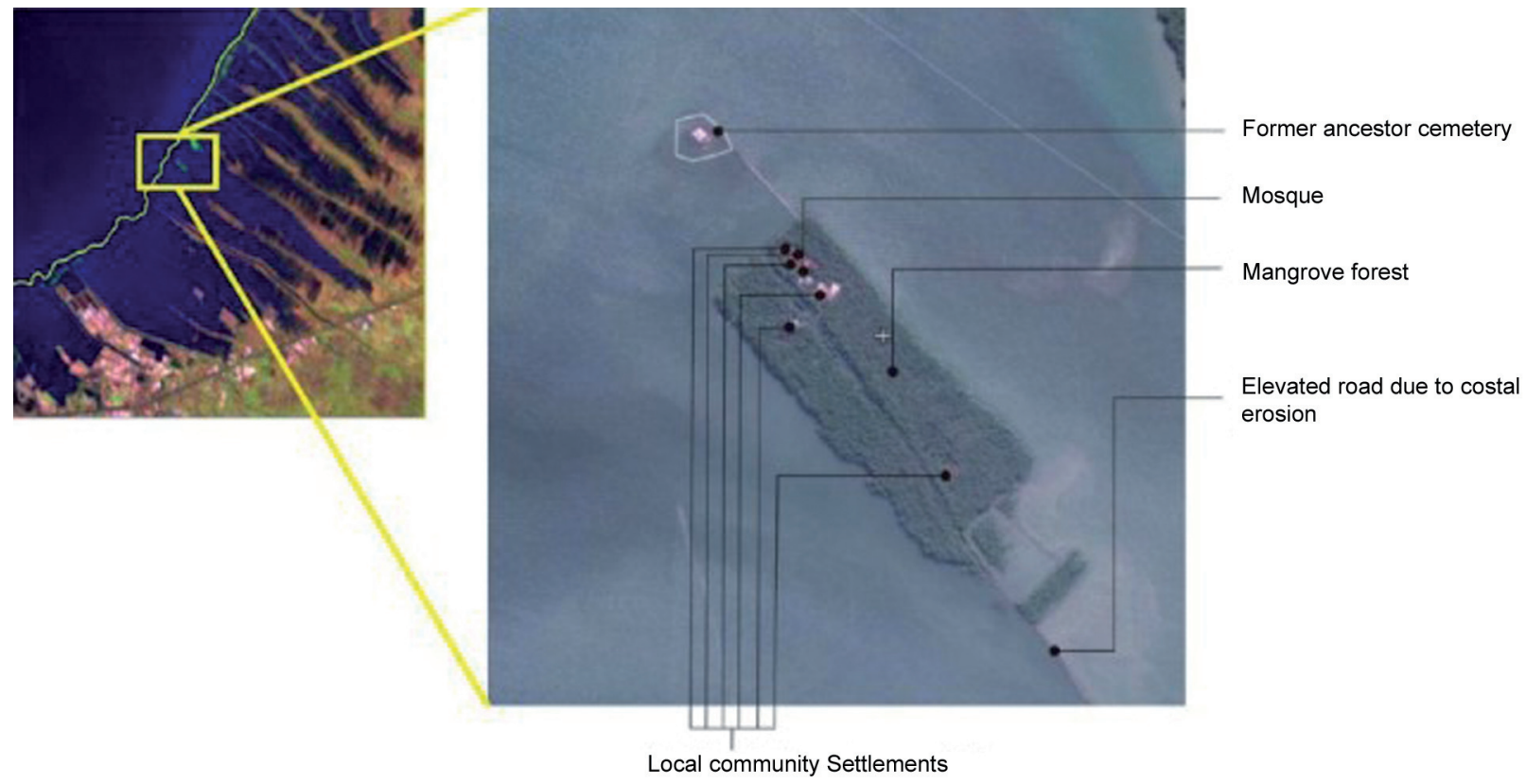

Fig. 3. High resolution image shown Tambaksari-Sayung area as the small area left due to coastal erosion. 
cause the coastal erosion destroyed their house. The coastal erosion was continuously destroying the area, reached to the almost $5 \mathrm{~km}$ to the mainland in 2005.

The changes of shoreline in Sayung area are shown in Fig. 2. The figure showing comparation of two landsat images which were taken in 1994 and 2006. Based on landsat images in 1994, the study location still had wide enough land connecting the study area with the mainland. Completely different condition found in the landsat image in 2006, in which the study location had separated with the mainland. High resolution image taken in 2011 has shown that there was small area of about 3.64 hectares left as the result of coastal erosion (Fig. 3). It also can been seen in the images whenever several houses still exist in that area, in which local community choose to stay and adapt instead of moving to the saver places.

\subsection{Impact of Coastal Erosion to the Communities}

Coastal erosion occurred in Sayung has devastating impact towards local communities. It has been mentioned that coastal erosion brought the

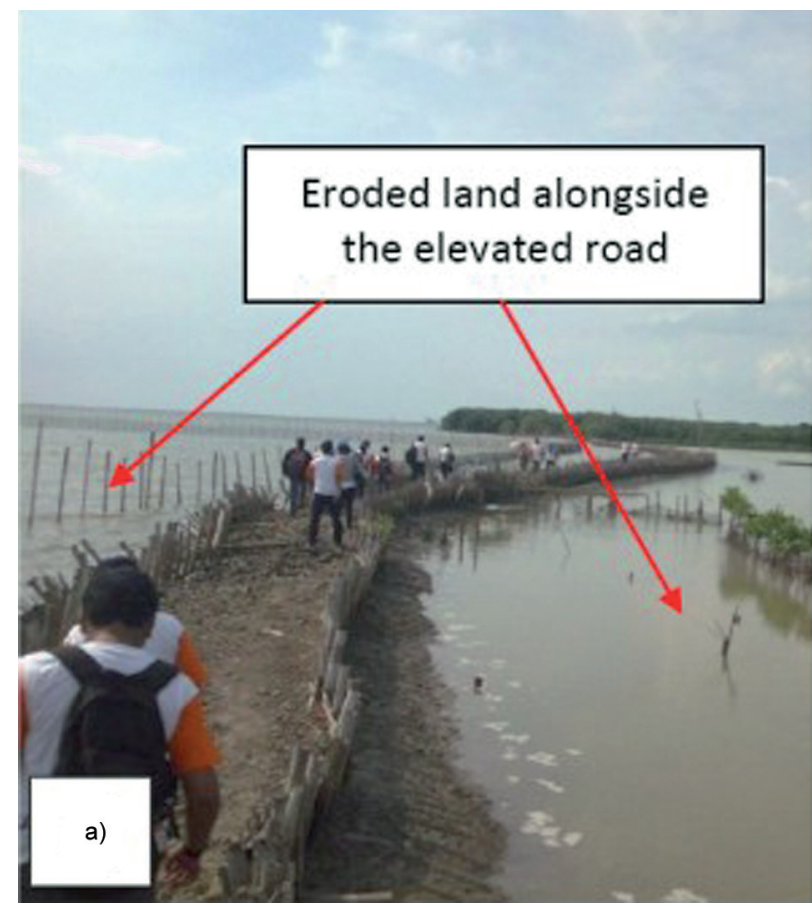

losses of the settlement, resulting of hundreds of household moved to the saver place. Besides of the impact towards settlement, the coastal erosion is also affecting the fishponds and infrastructures on the surrounding area (Fig. 4). It can be concluded that big economic losses is resulted as the impact of the coastal erosion.

At the beginning, the mangrove did not grow well in surrounding area due to human intervention. As shown in Figure 5, the land use in the study area is dominated by fishpond. This is related to the major occupancy of the local communities as fishermen or fishpond farmers. The fishponds in the study area extend from shoreline to the far away through the inland for about $5 \mathrm{~km}$ away from the sea. The past condition of coastal process, in which the shoreline was considered to be stable, became well suited with the fishponds farming in the area. Shifting of ocean current occurred after the development of Semarang Bay resulted in the enhancing coastal erosion process. Because no mangrove protected the area, massive erosion in fishpond area was occurred. As the result, most of the fishponds were destroyed and some of the fishpond farmers loss their main income.

Besides the fishpond farming area, the infrastructure, such as school, public cemetery, and

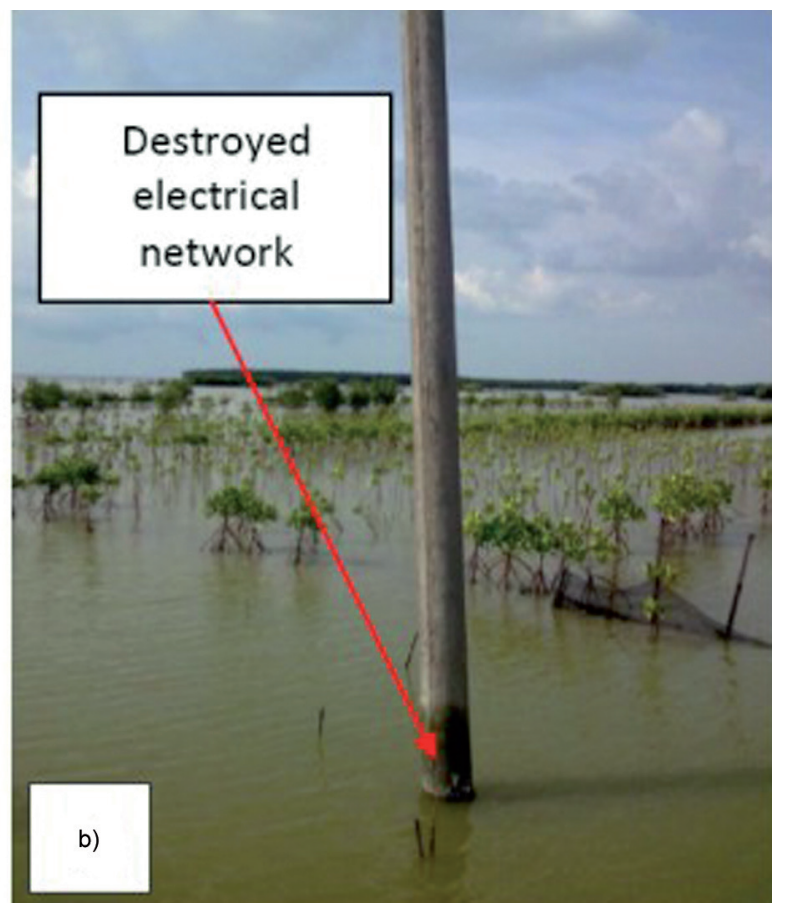

Fig. 4. The impact of coastal erosion to the land use.

(a) damaged land around the elevated road due to coastal erosion. (b) destroyed electrical networks. 


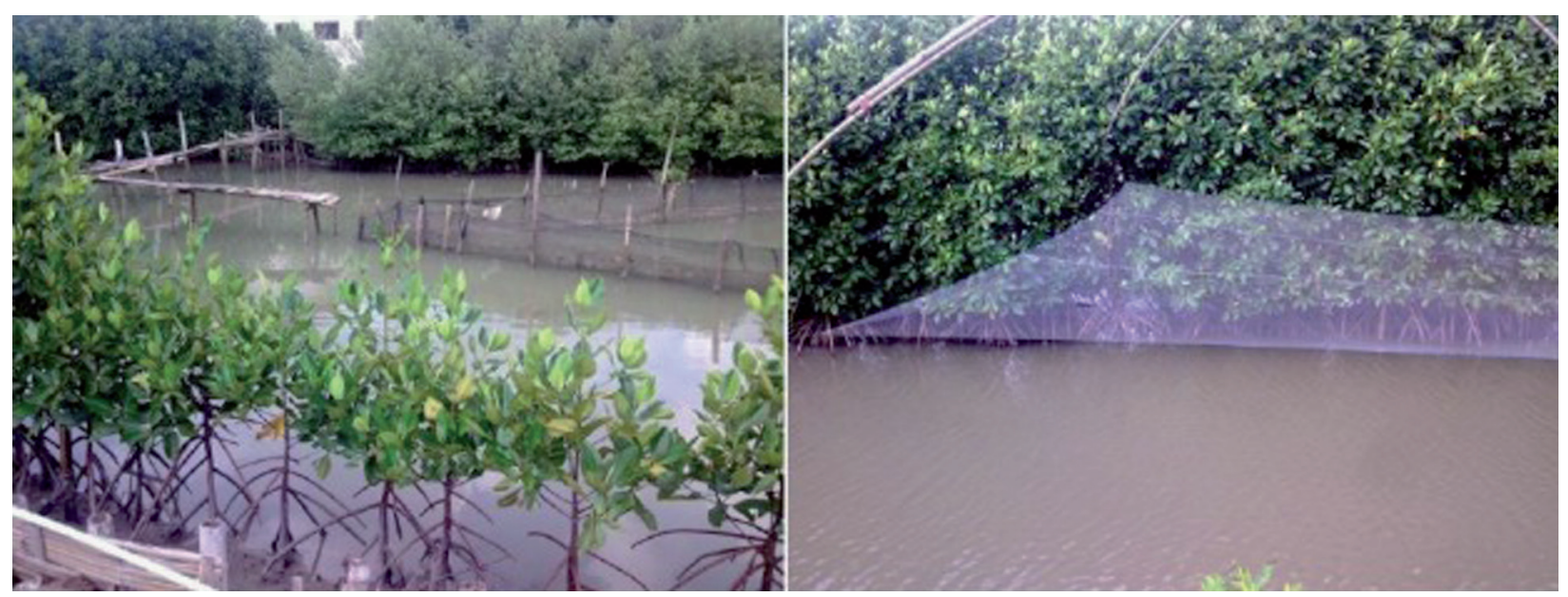

Fig. 5. Fishpond in study area.

electricity service also affected. As one of the result, the land value in Sayung is continuously decreasing. Before the coastal erosion occurred, the land value was about $\operatorname{Rp} 50,000 \mathrm{~m}^{-2}$. Due to coastal erosion, the land value is decreasing to $\mathrm{Rp}$ $4,000 \mathrm{~m}^{-2}$.

\subsection{Adaptation Strategy of Local Community of Sayung}

While the Sayung local community has limited options in coping with coastal erosion, the best option is to adapt with the changing environment. This condition found especially in Tambaksari, as a part of Sayung abrasion-prone area. Besides the coastal erosion, increasing tides due to sea level rise also causing the area to be inundated. Although several households have been relocated by the local government, some of them still live in this location. Therefore, for the people choose to stay, specific adaptation strategies must be implemented in order to survive.

Although the reason of why people still choose to live in the vulnerable area is different from one place to another place, local culture is considered the major driven factor. It can be found in Tambaksari area, in which preserving ancestor legalities becomes the main reason of why most inhabitants still live in the high vulnerable area. Most of the lands in Tambaksari has been endowed by their successor from generation over generation for very long time. Besides the limited knowledge on coastal erosion and sea level rise of the local inhabitants, the still trying to live in harmony with the changing environment.

At present, the population lives in Tambaksari is 50 inhabitants which are settled in 6 houses. Before the land of Tambaksari got separated with the mainland, most of the inhabitants are just ordinary fishermen and fishponds farmers. Since the coastal erosion continuously destroying the land, four of them became male patriarch working as cemetery keeper for their former ancestor, Syekh Mudzakir. As cemetery keeper, they work everyday to elevate the cemetery to prevent it from being hit by coastal erosion. Since they get only small income for their job, they also continue their work as fishermen, but only once a while whenever they need to fulfill their basic needs. Their incomes come from the cemetery visitor doing religious tourism. In addition to the patriarch which has non-fixed income, only 3 inhabitants of Tambaksari has fixed income from working in the private company.

Spiritual-belief system to their former ancestor by the local community in Tambaksari-Sayung is the major factor why the people in the area choose to adapt with the coastal erosion. As said in the interview conducted by this study, they will stay there as long as the land still exists. Therefore, several adaptation strategies have been developed by the inhabitants of Sayung. In the late of 2005, mangrove started to be planted in Tambaksari area with the financial support of international non-governmental organization (NGO). Further adaptation strategies then started to be developed in both environmental adaptation and social-economic adaptation. 


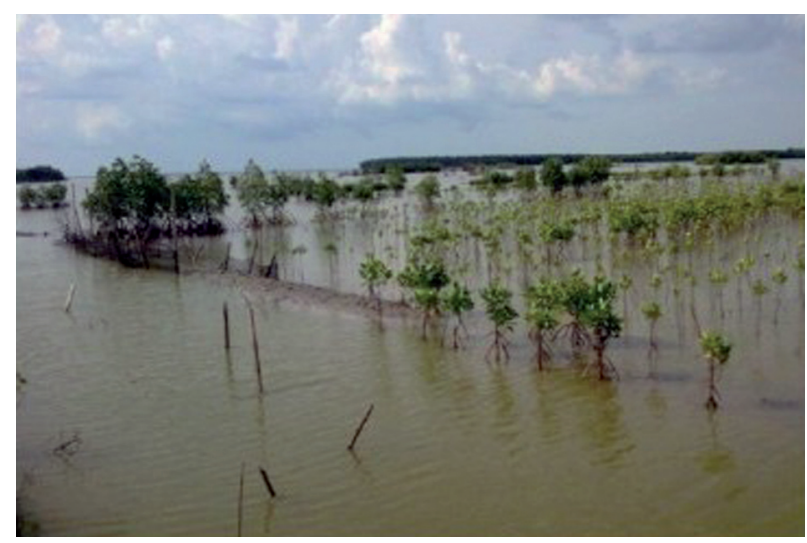

Fig. 6. Mangrove planted by local community of Tambaksari.

In adapting and reducing further impact of the coastal erosion, mangrove was planted by the local community of Sayung in December 2005. By the support of NGO and local government, the mangrove area increased. At present, mangrove plantation is proved to give major beneficiaries to the local community, especially with their function as protection barrier. The direct influence of sea wave and wind is much lower compared to the condition before, in which the mangrove was not exists. Therefore, the local community has high confidence with the mangrove plantation for supporting their lives and activities in sustainable manner (Fig. 6).

Mangrove ecosystem in Tambaksari area not only acts as natural barrier protecting the community from the coastal erosion, but also supports economic activities of the inhabitants. At present, mangrove ecosystem supports the food supply of the local community due to its suitability to grow fish, crab, and shrimp. Mangrove

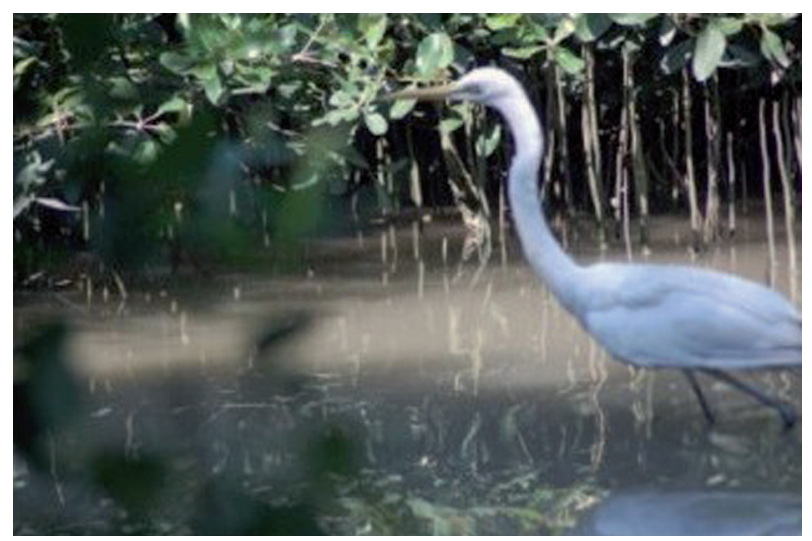

Fig. 7. Animal found in the mangrove area.

ecosystem in Tambaksari area also naturally acts as conservation area to the coastal animal. Some animals can be found in the mangrove forest, for especially birds and frogs (Fig. 7). This condition is causing the tourism activities to taken place, which generate new source of income for the inhabitants.

Physical adaptation to the environment from the local community has been found in various ways. As mentioned before, they continuously elevate the building due to increasing tides driven by sea level rise, in which the increasing rate is about $5 \mathrm{~cm} \mathrm{y}^{-1}$. Moreover, with the fund given by local government, they built staged house in preventing damages of coastal inundation to their house (Fig. 8). While the impact of coastal inundation to the house is now can be minimized by building staged house, the local inhabitants is now can utilize electronic devices (ex: television, refrigerator) with supports of the electricity in the location. Since the fresh water is relatively rare
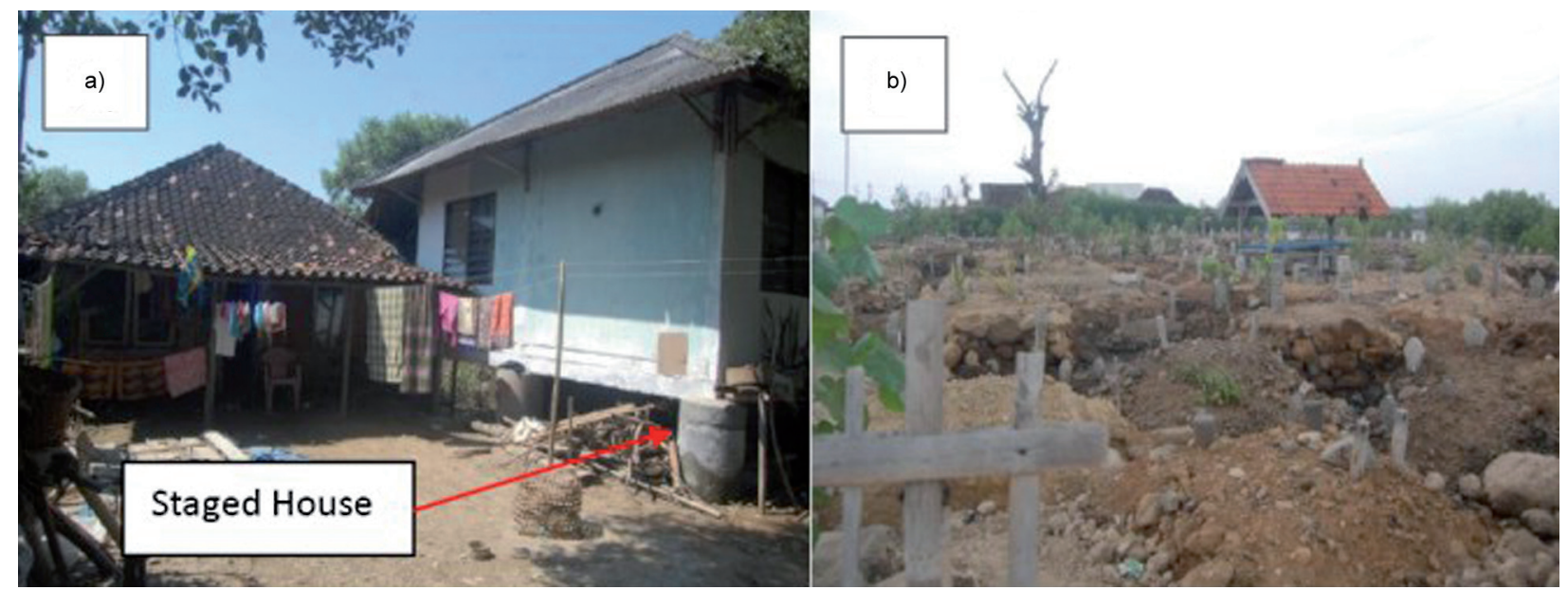

Fig. 8. (a) Staged house built by Tambaksari inhabitants, (b) elevated ground level to maintain the cemetery. 
in the area, they utilize deep groundwater taken from the well, in which the depth of the well is about 120 meters from the ground surface.

Social-economic adaptation also can be found in the local community of Tambaksari. Altough Tambaksari area now is separated to the mainland, social interaction of the Tambaksari people with larger communities of Sayung is still intensive. This condition resulted due to close family relationship between people in Tambaksari and mainland Sayung area. Therefore, they still visit each other especially when traditional ceremony held.

Economic adaptation found especially with the changing occupancy of people in Tambaksari. The past spiritual tourism in which the tourists visit the cemetery of Syekh Mudzakir combined with new mangrove tourism give new economic prosperity to the local community. At present, they sell food and souvenirs to the visitor coming to their area. Moreover, some of them rent a boat for the people who want to have a trip to see the coastal-mangrove ecosystem from the sea.

\section{Conclusions}

The severe coastal erosion has been found in Sayung coastal area. The coastal erosion has reached up to $5 \mathrm{~km}$ from the sea, resulting very devastating impact the local communities. As the impact of the coastal erosion, destruction of settlements, infrastructures, and fishponds has been occurred. The impact of coastal erosion also affected their socio-economic condition. Due to coastal erosion, fishpond farming activities running by most of the local community also severely damaged. Although, some of the Sayung inhabitants have been moved to the saver place, people live in Tambaksari rejected to be moved by local government. To overcome the impact of coastal erosion, local communities developed specific adaptation strategies, both in the terms of physical adaptation and social-economic adaptation. Physical adaptation by local community held by planting mangrove in the shoreline of Tambaksari, elevating the ground level, building staged house, using freshwater extracted from deep well. Social-economic adaptation is held by keeping social interaction with the larger communi- ties in the mainland, gathering the food from the mangrove, and turning job into tourism sector. While the inhabitants live in very vulnerable area affected by coastal erosion, the local community of Tambaksari area has developed successful adaptation strategies in coping with the coastal erosion. Therefore, supports from the local government and NGO in developing future mitigation and adaptation strategies are required, especially in the mangrove conservation and physical infrastructure development.

\section{Acknowledgements}

This research has been supported by grant of Beasiswa Unggulan Program Pengembangan Doktor (P2D) 2012 by Bureau of international planning and cooperation, Ministry of Education and Culture of Republic Indonesia. Thanks are due to Nursakti Adhi P and Andung Bayu Sekaranom for their help during the fieldwork.

\section{References}

BAgli S. \& Sollle P., 2003. Morphological Automatic Extraction of Pan-European Coastline from Landsat ETM+images. International symposium on GIS and Computer Cartography for Coastal Management, October, Genova.

Bird E.C.F. \& ONGKOSONGO O.S.R., 1980. Environmental changes on The Coast of Indonesia. The United Nations University, United Nations University Press.

Hardoyo S.R., Marfai M.A., NI'MAH N.M., MuKti R.Y., ZAHro Q. \& Halim A., 2012. Communities Adaptation strategies Due to Coastal Flood Disaster in Pekalongan. Cahaya Press, Yogyakarta, Indonesia.

Mardiatno D., Marfai M.A., Rahmawati K., Tanjung R., SianTURI R.S. \& Mutiarni Y.S., 2012. Multirisk Assesment of Coastal and River Floods in Pekalongan Utara. Cahaya Press, Yogyakarta, Indonesia.

Marfai M.A., 2011a. The Hazards of Coastal Erosion in Central Java, Indonesia: An Overview. GEOGRAFIA Malaysia Journal of Society and Space, 7(3): 1-9.

MARFAi M.A., 2011b. Impact of Coastal Inundation on Ecology and Agricultural Land Use, Case Study in Central Java, Indonesia. Quaestiones Geographicae, 30(3): 19-32, DOI: 10.2478/v10117-011-0024-y.

Marfai M.A., 2011c. Community's adaptive capacity due to coastal flooding in Semarang Coastal City, Indonesia. International Journal of Seria Geografie. Annals of the University of Oradea, XXI (2/2011, December): 209-221.

Marfai M.A., Almohammad H., Dey S., Susanto B. \& King L., 2008b. Coastal Dynamic \& Shoreline Mapping: Multisources Spatial Data Analysis in Semarang Indonesia. Environmental Monitoring Assessment, 142: 297-308, DOI: 10.1007/s10661-007-9929-2. 
Marfai M.A. \& King L., 2007. Monitoring land subsidence in Semarang, Indonesia. Environmental Geology, 53: 651-659, DOI: $10.1007 /$ s00254-007-0680-3.

Marfai M.A. \& King L., 2008. Potential vulnerability implications of coastal inundation due to sea level rise for the coastal zone of Semarang city, Indonesia. Environmental Geology, 54: 1235-1245, DOI: 10.1007/s00254-007-0906-4.

Marfai M.A., King L., Singh L.P., Mardiatno D., Sartohadi S., SRI HADMOKo D. \& DeWi A., 2008a. Natural hazards in Central Java-Indonesia: an overview. Environmental Geology, 56: 335-351, DOI: 10.1007/s00254-007-1169-9.

Marfai M.A. \& Mardiatno D., 2010. Potential and Environmental Problems in the Watershed and the Coastal Region. Case Study Sub watershed Kuto, Damar, and Blukar. BPFG, Yogyakarta, Indonesia.

Marfai M.A., Pratomoatmojo N.A., Hidayatullah T., NirWANSYAH A.W. \& GomareuZZAMAn M., 2011. Modelling of Coastal Vulnerability based on Shoreline Change and Coastal Flooding (A Case Study of Pekalongan Coastal Area). Cahaya Press, Yogyakarta, Indonesia.
Marfai M.A., Yulianto F. \& Hizbaron D.R., 2009. Modeling of the effect of climate and socioeconomic changes on potential flood damage in Jakarta. Free University of Amsterdam.

MAUlina N., 2010. Shoreline Change Analysis and Prediction; An Application of Remote Sensing and GIS. M.Sc Thesis. Gadjah Mada University, Yogyakarta, Indonesia.

Mills J.P., Buckley S.J., Mitchell H.L., Clarke P.J. \& Edwards S.J., 2005. A Geomatic Data Integration Technique for Coastal Change Monitoring. Earth Surface Processes and Landforms, 30: 651-664.

Purnama I.L.S., Trijuni S., Hanafi F., Aulia T. \& Razali R., 2012. Water Balance Analysis in Kupang and Sengkarang Watershed. Cahaya Press, Yogyakarta, Indonesia.

Sartohadi J., Marfai M.A. \& Mardiatno D., 2009. Coastal zone management due to abrasion along the coastal area of Tegal, Central Java Indonesia. Proceeding International Coastal Conference, Nagoya Japan, 23-25 February 2009: 37-44.

SunArto, 2004. Geomorphic Changes in Coastal Area Surround Muria Volcano. PhD dissertation. Gadjah Mada University, Yogyakarta, Indonesia (in Indonesian). 